\title{
The Effectiveness of CT Enterography in the Radiological Evaluation of Crohn's Disease
}

\section{Crohn Hastalığının Radyolojik Değerlendirmesinde BT Enterografisinin Etkinliği}

\section{(D) Nevzat Herdem¹, (D) Deniz Esin Tekcan Şanlı2,3}

1Erciyes University Faculty of Medicine, Department of Radiology, Kayseri, Turkey

${ }^{2}$ Acıbadem Kozyatağı Hospital, Clinic of Radiology, İstanbul, Turkey

3İstanbul Rumeli University, Vocational School of Health Services, Department of Medical Imaging Techniques, İstanbul, Turkey

\section{Abstract}

Objective: The aim of this study is to evaluate the effectiveness of computed tomography enterography (CTE) in demonstrating luminal and extraluminal pathologies in patients diagnosed with Crohn's disease (CD).

Method: In 20 symptomatic patients histopathologically diagnosed with $C D, C T E$ findings obtained after optimal bowel distension with oral contrast material were evaluated retrospectively. The involved segment was evaluated in terms of the presence of intestinal wall thickening (focal or diffuse), pathological contrast enhancement in the intestinal wall, increased vascularity in the intestinal mesentery, mesenteric lymphadenopathy, intraperitoneal fluid, enteric fistula, and intraabdominal abscess. In addition, evaluation was made in terms of extraintestinal findings that might be related to the disease.

Results: A total of 20 patients ( 11 females, 9 males; age range: 24 to 61 years, mean age: $39.7 \pm 11.4$ years) were included in the study. The most frequently affected intestinal segment was the terminal ileum $(n=10$, $50 \%)$. Pathological intestinal wall enhancement was detected in 14 patients (70\%), mesenteric lymphadenopathy in 16 patients (80\%), and comb sign in 15 patients (75\%). Intraabdominal abscess was detected in 4 cases $(20 \%)$ and enteric fistula in 4 cases (20\%). Related to the disease, kidney stones in one patient and previous cholecystectomy findings in two patients were observed.

Conclusion: CTE is a very effective method that can simultaneously monitor the intestinal and extraintestinal findings of the symptomatic patients with $C D$ and guide the treatment choice.

Keywords: Abscess, complication, Crohn's disease, CT enterography, enteroclysis, fistula, wall thickening

\section{Öz}

Amaç: Bu çalışmanın amacı, bilgisayarlı tomografi enterografisinin (BTE) Crohn hastalığı $(\mathrm{CH})$ tanısı almış hastalarda lümen içi ve lümen dışı patolojileri göstermedeki etkinliğini değerlendirmektir.

Yöntem: Histopatolojik olarak $\mathrm{CH}$ tanısı konulan semptomatik 20 hastada oral kontrast madde ile optimal barsak distansiyonu sonrası elde edilen BTE bulguları geriye dönük olarak değerlendirildi. Tutulan segment intestinal duvar kalınlaşması (fokal veya diffüz), bağırsak duvarında patolojik kontrastlanma, intestinal mezenterde artmış vaskülerite, mezenterik lenfadenopati, intraperitoneal sıvı, enterik fistül, intraabdominal apse varlığı açısından değerlendirildi. Ayrıca hastalığa bağı olabilecek ekstraintestinal bulgular açısından değerlendirme yapıldı.

Bulgular: Çalışmaya toplam 20 hasta (11 kadın, 9 erkek; yaş aralığı: 24-

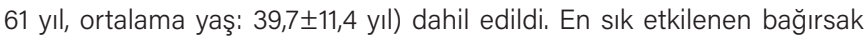
segmenti terminal ileumdu ( $n=10, \% 50)$. On dört hastada (\%70) patolojik bağırsak duvarında kontrastlanma, 16 hastada (\%80) mezenterik lenfadenopati ve 15 hastada (\%75) tarak işareti saptandı. Dört olguda (\%20) karın içi apse ve 4 olguda (\%20) enterik fistül tespit edildi. Hastalıkla ilgili olarak, bir hastada böbrek taşı ve iki hastada geçirilmiş kolesistektomi bulguları izlendi.

Sonuç: BTE, CH olan semptomatik hastaların intestinal ve ekstraintestinal bulgularını eş zamanlı olarak izleyebilen ve tedavi seçimine yön verebilen çok etkili bir yöntemdir.

Anahtar kelimeler: Apse, BT enterografisi, Crohn hastalığı, duvar kalınlaşması, enterokliz, fistül, komplikasyon

Address for Correspondence: Deniz Esin Tekcan Şanlı, Acıbadem Kozyatağı Hospital, Clinic of Radiology; İstanbul Rumeli University, Vocational School of Health Services, Department of Medical Imaging Techniques, İstanbul, Turkey

E-mail: tekcandenizesin@gmail.com ORCID: orcid.org/0000-0002-6545-5757 Received: 02.02.2021 Accepted: 23.06.2021

Cite this article as: Herdem N, Tekcan Şanlı DE. The Effectiveness of CT Enterography in the Radiological Evaluation of Crohn's Disease. Bagcilar Med Bull 2021;6(3):257-263

${ }^{\circ}$ Copyright 2021 by the Health Sciences University Turkey, Bagcilar Training and Research Hospital Bagcilar Medical Bulletin published by Galenos Publishing House. 


\section{Introduction}

Crohn's disease (CD) is a transmural disease that can affect all parts of the gastrointestinal tract from the mouth to the anus, which typically involves the terminal ileum (1). The disease, which progresses with relapses and remissions, shows a bimodal distribution, and most frequently affects young adults. Inflammation, which is limited to the mucosa in the early period, deepens as the disease progresses and affects other layers of the intestine and may even exceed the serosa, leading to complications such as perforation, abscess, and fistula (2-4). It may involve multiple segments where the loops remain normal (skip lesion). While obstruction secondary to spasm due to mucosal inflammation and irritation can be seen in the intestinal passage in the acute or active period (string sign), in the chronic period, obstructions due to strictures that occur as a result of healing with fibrosis can be seen. In addition, in the active phase of the disease, prominence of mesenteric vascular structures (comb sign), mesenteric lymphadenopathy and intraabdominal fluid can be seen (2).

Despite technological advances in imaging methods, difficulties are still encountered in the diagnosis of CD. Since it is difficult to reach the small intestine with endoscopic methods, the effectiveness of endoscopy is limited in the histopathological diagnosis of the disease that mainly affects the small intestine. Although new techniques such as capsule endoscopy and double balloon endoscopy have been developed, their use has not become widespread because they require expensive equipment, do not show extraluminal pathologies and do not allow therapeutic procedures (5-7). Therefore, radiological methods still maintain their importance not only in the diagnosis of $\mathrm{CD}$ but also in showing the signs of activation and complications. Until the 2000s, enteroclysis has been the gold standard method in CD imaging because it allows the evaluation of mucosal pathologies and bowel functions (8-10). Enteroclysis has begun to leave its place to cross- sectional imaging methods because it is an invasive method, unable to show extraluminal pathologies. Another disadvantage of enteroclysis is excessive radiation exposure. With the isotropic resolution properties of multidetector computed tomography (CT) devices developed in recent years, images with a thickness of less than 1 $\mathrm{mm}$ and multiplanar reformat images obtained during a single breath hold allow much more detailed evaluation of small bowel pathologies and extraluminal findings, and play an important role in revealing complications (11-
14). Similarly, with the high soft tissue resolution and the development of rapid new sequences, magnetic resonance imaging (MRI) has taken its place among the radiological methods in the diagnosis of CT enterography (CTE) and revealing complications (15-18).

In this study, we aimed to evaluate luminal and extraluminal pathologies detected by CTE in symptomatic cases with histopathologically diagnosed $\mathrm{CD}$ and to compare our findings with the literature.

\section{Materials and Methods}

\section{Study Population}

Between August 2014 and February 2016, imaging findings of 65 patients who underwent CTE due to the diagnosis or activation suspicion of $\mathrm{CD}$ were evaluated retrospectively. Fourty-five patients were excluded because they had no histopathological diagnosis of CD. In addition, patients over 65 years of age, patients with benign prostatic hyperplasia, myasthenia gravis, congestive heart failure, glaucoma, and patients with contrast allergy were not included in the study. Ethics committee approval of Erciyes University numbered 2016/291 was obtained for the study.

\section{Imaging Method}

Liquid diet was applied to all patients for 1 day before the examination and all patients fasted for 8 hours before the procedure. In order to provide bowel distension, the patients were given an oral contrast solution obtained from 1 liter of drinking water and 1 liter of $20 \%$ mannitol within 45 minutes before the examination. In the $45^{\text {th }}$ minute, the patients were taken to the CT unit and manually $20 \mathrm{mg}$ intravenous (I.V.) hyosine-n-butyl bromide (Buscopan) and $120 \mathrm{~mL}$ I.V. non-ionic iodine concentration $350 \mathrm{mg} / 100$ $\mathrm{mL}$ contrast material were given via automatic injector at $4 \mathrm{~mL} / \mathrm{sec}$. and in the $30^{\text {th }}$ second, single- phase acquisition was made with a 320-detector CT device (Toshiba Aquilion ONE 320 detector CT scanner). After obtaining images with $5 \mathrm{~mm}$ sections and $1.25 \mathrm{~mm}$ thin sections in the axial plan, reformatted images were created in the coronal and sagittal planes.

\section{Image Analysis}

Measuring the intestinal wall thickness above $3 \mathrm{~mm}$ in the distended bowel segments was considered pathological. Intestinal segments with higher density than normal bowel segments were evaluated in favor of pathological wall enhancement. Mesenteric lymph nodes with a short axis greater than $5 \mathrm{~mm}$ were considered pathological. Linear 
tracts observed between two epithelial surfaces in the intestinal loops were evaluated as fistula, and peripheral contrast-enhancing fluid collections as abscesses. In addition, evaluation was made in terms of extraintestinal findings that might be related to the disease (cholelithiasis, nephrolithiasis).

\section{Statistical Analysis}

SPSS 21 (SPSS Inc. IBM company, Chicago) program was used for statistical analysis. Descriptive data were presented as mean, standard deviation, minimum and maximum values, frequency and ratio. As the overall number of cases was relatively small, no inferential statistical analysis was undertaken.

\section{Results}

Of the patients participating in the study, 9 (45\%) were male and 11 were female (55\%). The average age of the patients was 39.7 \pm 11.4 (24-61) years. The most commonly involved segment was terminal ileum $(n=10,50 \%)$. Pathological wall thickening was detected in 15 patients (75\%) and wall enhancement in 14 patients. Pathological wall thickening was detected in all patients with wall enhancement. No intestinal segment involvement was observed in five patients. All involved segments in order of frequency were demonstrated in Table 1.

Abscess was detected in four cases (20\%). One patient with an abscess had undergone surgery previously because of colon perforation and a colostomy was present on CTE. Bowel involvement was not present in one case with multiple intraabdominal abscesses. In another case, pathological wall thickening and wall enhancement were observed in the ascendant colon, and the abscess appeared as microabscesses around the colon. The fistula was observed in 4 cases (20\%). There were ileoileal and

\begin{tabular}{ll} 
Table 1. Involved bowel segments in order of frequency \\
Involved segment & Number (n) percent (\%) \\
\hline Terminal ileum & $10(50 \%)$ \\
Distal ileum & $7(35 \%)$ \\
Cecum & $6(30 \%)$ \\
Sigmoid colon & $4(20 \%)$ \\
Ascending colon & $4(20 \%)$ \\
Transverse colon & $3(15 \%)$ \\
Rectum & $3(15 \%)$ \\
Jejunum & $2(10 \%)$ \\
Descending colon & $2(10 \%)$ \\
Appendix & $1(5 \%)$ \\
\hline
\end{tabular}

ileojejunal fistulas in one case and ileocolic in the other cases. Fistula and abscess were present together in two cases.

Mesenteric lymphadenopathy (LAP) was detected in 16 cases (80\%) and comb sign in 15 cases (75\%). Comb sign and mesenteric LAP were present in all cases with pathological wall thickening. The case with mesenteric LAP without intestinal involvement was a 32-year-old female patient diagnosed with $\mathrm{CD}$ three years ago. Ileus was detected in 1 case and ileocecal invagination in 1 case. Pathologic findings of CD on CTE was demonstrated in Table 2.

Among the extraintestinal findings that may be associated with the disease, kidney stones in 1 case and findings from previous cholecystectomy in 2 cases were observed. In addition, findings not related to $\mathrm{CD}$, nodule in the liver in three cases, infarct in the spleen in one case, and mass in the uterus in one case were detected incidentally. Sample cases were shown in Figures 1-5.

\section{Discussion}

Enteroclysis, which is the gold standard diagnostic method in the evaluation of CD and other small bowel pathologies, has begun to be abandoned today because of its invasive nature, and diagnostic quality depends on the practitioner and the device (19). It is not available in every center and the examination period is long (8-10). In addition to the diagnosis of the disease with crosssectional imaging methods, the simultaneous detection of activation and complication findings is one of the important reasons leading to this situation. In studies comparing enteroclysis and CTE, no significant difference was found between the two methods in terms of their ability to show mucosal and mural pathologies (19). In addition, CTE has been shown to be superior in detecting transmural spread patterns such as fistula and abscess, which are important for treatment planning and patient management, intra-abdominal fluid, mesenteric LAP, increased vascularity and extraintestinal involvement (20-23). Also, evaluation of upper gastrointestinal Table 2. Pathologic findings of Crohn's disease on CTE

\begin{tabular}{ll} 
Finding & Number (n) percent (\%) \\
\hline Intestinal wall thickening & $15(75 \%)$ \\
Mural enhancement & $14(70 \%)$ \\
Abscess & $4(20 \%)$ \\
Fistula & $4(20 \%)$ \\
Mesenteric LAP & $16(80 \%)$ \\
\hline CTE: Computed tomography enterography, LAP: Leukocyte Lymphadenopathy, \\
comb sign 15 (75\%)
\end{tabular}


and colon involvement, detection of skip lesions and detection of conglomeration-separation findings in the intestinal folds were found to be higher in CTE (20-23).

One of the most important aspects in the detection of small bowel pathologies, especially mucosal lesions, pathological wall thickening, presence of fistula and the degree of obstruction is to provide optimal intestinal distension $(24,25)$. It may cause false positives in the

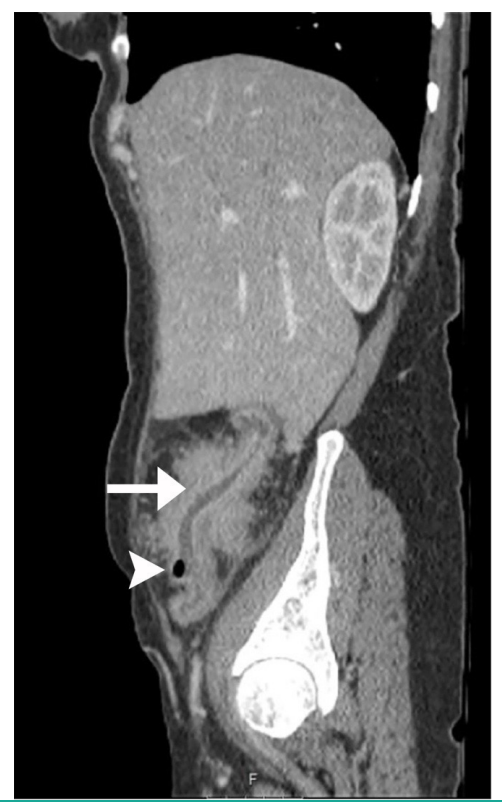

Figure 1a. In a 42-year-old female case, sagittal CTE image shows thickening, enhancement of the mucosa (white arrow) and gas density (arrowhead) adjacent to the anterior colon wall

CTE: Computed tomography enterography

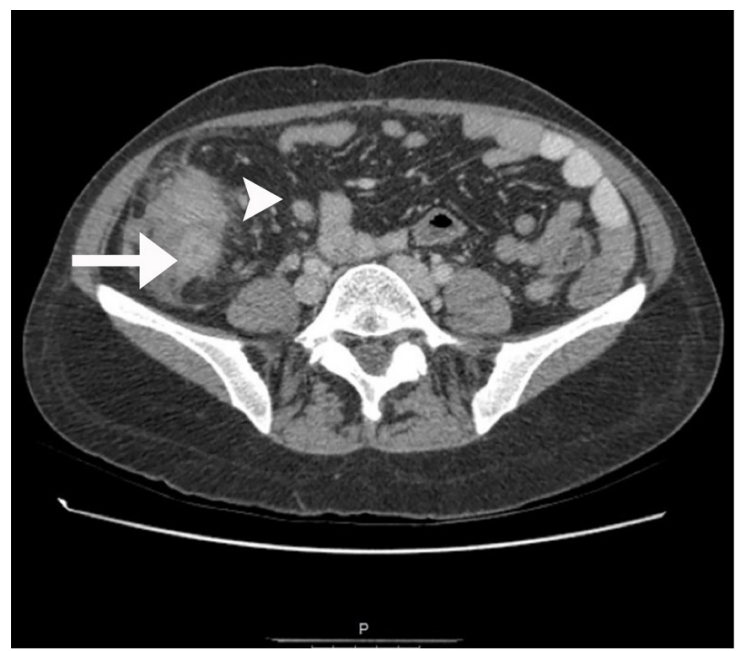

Figure 1b. In the axial view, the lymph node (arrowhead) is seen in the mesenteric fatty plans, adjacent to the thickening and enhancement of the wall (white arrow), with a peripheral enhancing microabscess (arrowhead) evaluation of wall thickening and deficiencies in stenotic segment-stricture evaluations in insufficiently distended bowel loops. Also, artifacts caused by intestinal peristaltic activity limit the evaluation of mucosal and mural lesions in particular. With the development of multidetector CT devices, serial images can be obtained in a very short time and by the development of rapid MRI sequences, the wrong evaluations due to these artifacts have been relatively prevented. In addition, I.V. hyosine-n-butyl bromide

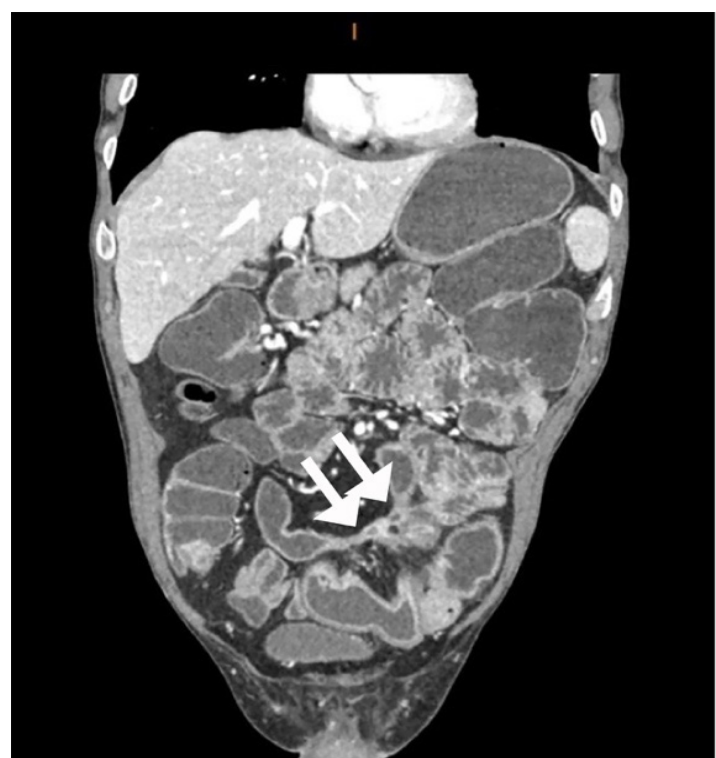

Figure 2a. In a 46-year-old male case, coronal CTE image shows fistula tracts (white arrow) extending from the distal ileum to the sigmoid colon

CTE: Computed tomography enterography

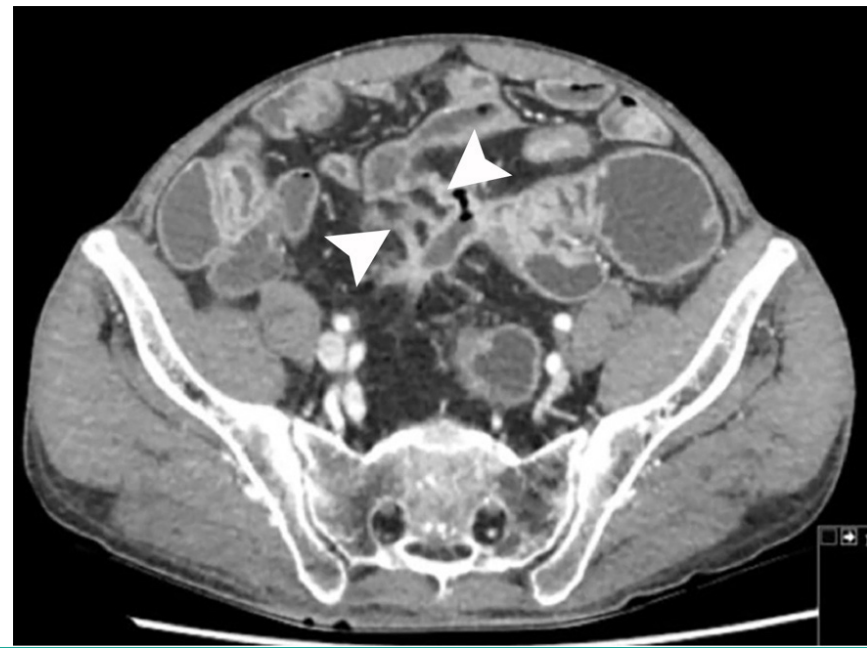

Figure 2b. In the axial section, fistula tracts (arrowheads) extending between the ileal loops and sigmoid colon, and also the neighboring mesenteric fatty tissues are contaminated 


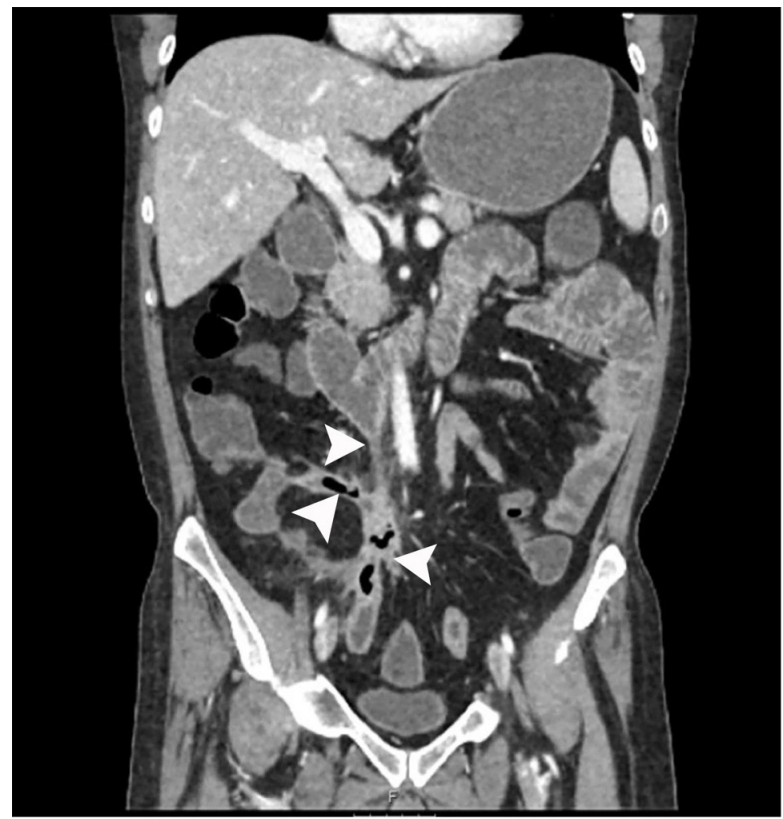

Figure 3. In a 43-year-old male patient, multiple fistula tracts (arrowheads) are observed between the ileal and jejunal segments in the coronal CTE image

CTE: Computed tomography enterography

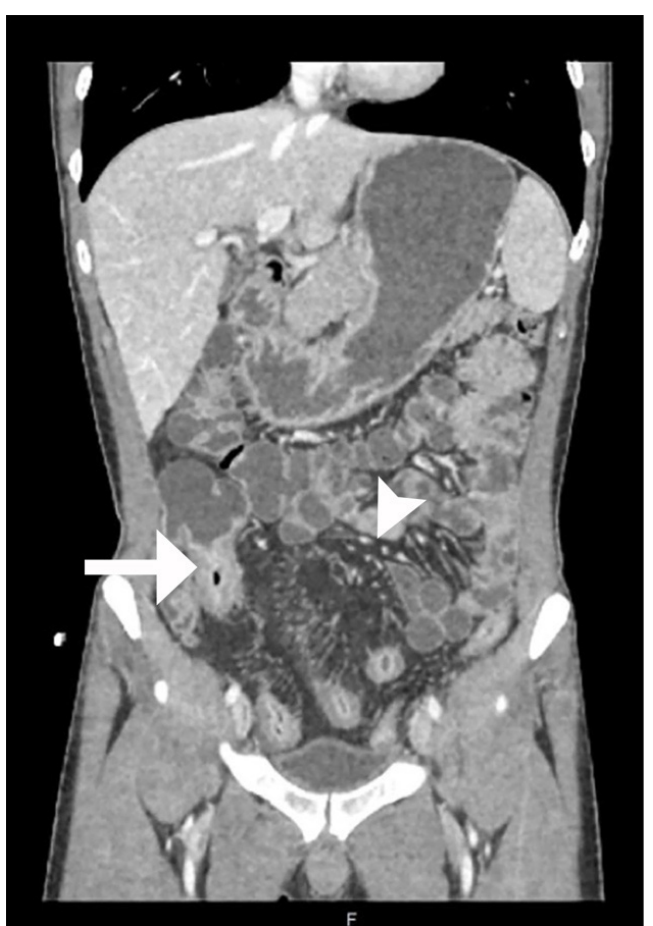

Figure 4a. In a 31-year-old male patient with a history of operation due to Crohn's disease, coronal CTE image shows thickening of the ileum wall adjacent to the anastomosis line and mucosal enhancement (white arrow). Note the increase in mesenteric vascularity (comb sign) (arrowheads)

CTE: Computed tomography enterography

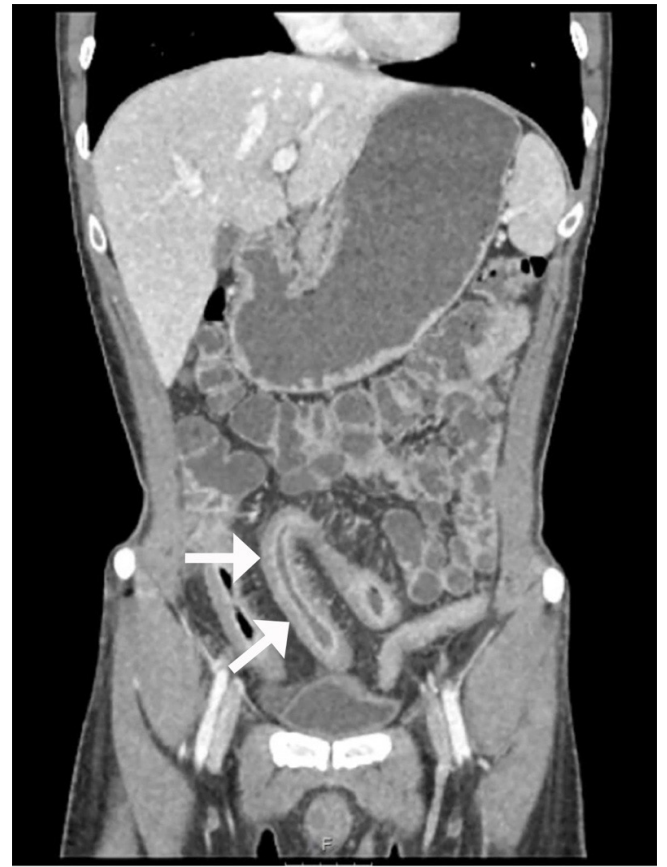

Figure $4 \mathbf{b}$. In the coronal view, wall thickening and mucosal enhancement in the ileum (white arrows) and adjacent vascular engorgement-comb sign are seen

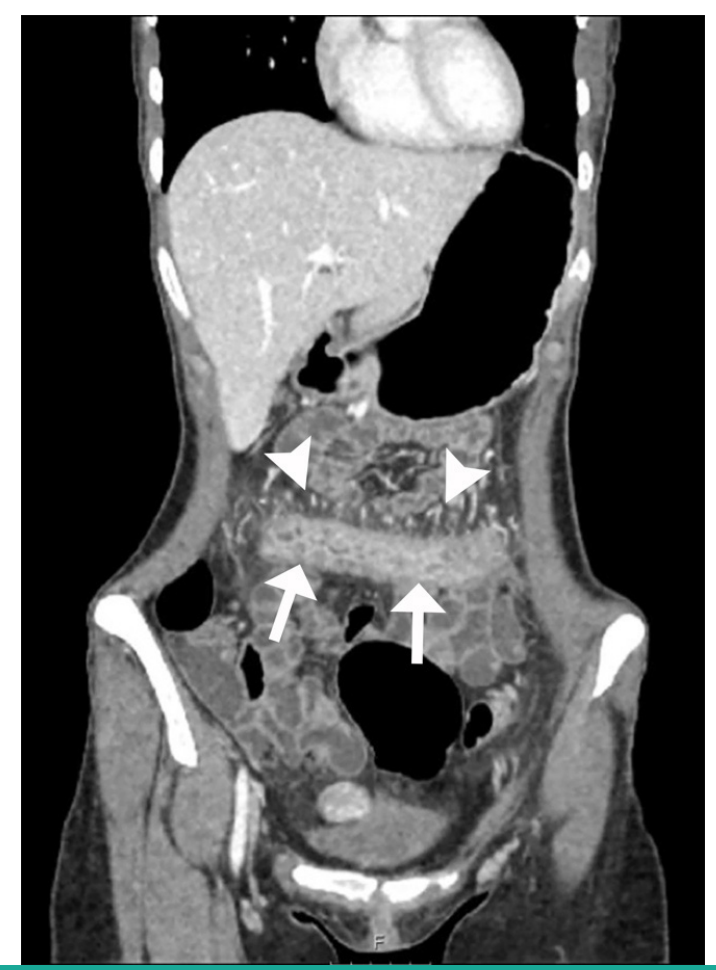

Figure 5. A 23-year-old female case, the coronal CTE image shows diffuse wall thickening of the transverse colon, cobblestone pattern (white arrows), and adjacent mucosal enhancement with venous engorgement (arrowheads) and lymph node

CTE: Computed tomography enterography 
(buscopan), which is administered just before extraction in order to reduce bowel movements, helps to overcome this limitation $(24,25)$.

In the diagnosis of $\mathrm{CD}$ and the detection of complications, CTE is a very useful and practical imaging method compared to other radiological methods because it is a non-invasive method that is easy to access and apply. The most important disadvantage of CTE is radiation exposure (26). Due to the fact that the majority of the patients are young and the nature of the disease is relapse-remission, this situation becomes more frightening in repeated applications $(9,27)$. However, with new and fast devices and calibration settings that keep up with developing technological changes, the radiation effect has been reduced to insignificant levels.

In this study, in accordance with the literature, the most commonly involved segment was terminal ileum. In addition to diffuse colonic involvement, isolated appendix involvement was found in one case. Isolated appendix involvement in CD is very rare in the literature $(28,29)$.

Lo Re et al. (30) reported upper gastrointestinal system involvement as $3.2 \%$ in their study. In our study, esophagusstomach involvement of the upper gastrointestinal system was not detected. In our study, the rate of fistula detection was found to be $20 \%$, and all of them were entero-enteric fistulas. Similar rates were obtained in studies aiming to measure the prevalence of penetrating disease and extraintestinal pathology. The rate of fistula and sinus tract was reported as $32 \%$ by Goldberg et al. (31), and $17 \%$ by Bruining et al. (21). Also, abscess detection rate $(20 \%)$ in our study was consistent with the literature (32).

\section{Study Limitations}

The major limitation of our single center retrospective study was the small number of patients. In addition, we could not compare the luminal and extraluminal CTE findings of the disease with other radiological methods such as enteroclysis and MRI. In this respect, studies that compare with other modalities with higher number of patients can be tried in the future.

\section{Conclusion}

CTE plays a key role in patient management and treatment planning in $\mathrm{CD}$, as it provides the opportunity to show diagnosis-activation-complication findings in a single session. Although radiation exposure seems to be a disadvantage especially for the young patient group, this handicap has been prevented with new multidetector CT devices.

\section{Ethics}

Ethics Committee Approval: Ethics committee approval of Erciyes University Faculty of Medicine numbered 2016/291 was obtained for the study.

Informed Consent: Written informed consent was not necessary because no patient data have been included in the manuscript.

Peer-review: Externally peer-reviewed.

\section{Authorship Contributions}

Concept: N.H., D.E.T.Ş., Design: N.H., D.E.T.Ş., Data Collection or Processing: N.H., D.E.T.Ş., Analysis or Interpretation: N.H., D.E.T.Ş., Writing: N.H., D.E.T.Ş.

Conflict of Interest: No conflict of interest was declared by the authors.

Financial Disclosure: The authors declared that this study received no financial support.

\section{References}

1. Lopes S, Andrade P, Afonso J, Cunha R, Rodrigues-Pinto E, Ramos I, et al. Monitoring Crohn's disease activity: endoscopy, fecal markers and computed tomography enterography. Therap Adv Gastroenterol 2018;11:1756284818769075.

2. Carbo AI, Reddy T, Gates T, Vesa T, Thomas J, Gonzalez E. The most characteristic lesions and radiologic signs of Crohn disease of the small bowel: air enteroclysis, MDCT, endoscopy, and pathology. Abdom Imaging 2014;39(1):215-234.

3. Scharitzer M, Koizar B, Vogelsang H, Bergmann M, Primas C, Weber M, et al. Crohn's disease: prevalence, MR features, and clinical significance of enteric and colonic sinus tracts. Eur Radiol 2020;30(10):5358-5366

4. Lightner AL, Ashburn JH, Brar MS, Carvello M, Chandrasinghe P, van Overstraeten AB, et al. Fistulizing Crohn's disease. Curr Probl Surg 2020;57(11):100808.

5. Yang DH, Keum B, Jeen YT. Capsule Endoscopy for Crohn's Disease: Current Status of Diagnosis and Management. Gastroenterol Res Pract 2016;2016:8236367.

6. Huang Z, Liu X, Yang F, Wang G, Ge N, Wang S, Guo J, Sun S. Diagnostic efficacy of double-balloon enteroscopy in patients with suspected isolated small bowel Crohn's disease. BMC Gastroenterol 2020;20(1):42.

7. Pennazio M, Spada C, Eliakim R, Keuchel M, May A, Mulder CJ, et al Small-bowel capsule endoscopy and device-assisted enteroscopy for diagnosis and treatment of small-bowel disorders: European Society of Gastrointestinal Endoscopy (ESGE) Clinical Guideline. Endoscopy 2015;47(4):352-376.

8. Akman C, Korman U, Oğüt G, Kuruğoğlu S, Urger E, Ulus S, et al A combination of small bowel imaging methods: conventional enteroclysis with complementary magnetic resonance enteroclysis. Clin Radiol 2005;60(7):778-786.

9. Masselli G, Vecchioli A, Gualdi GF. Crohn disease of the small bowel: MR enteroclysis versus conventional enteroclysis. Abdom Imaging 2006;31(4):400-409. 
10. Korman U, Kurugoglu S, Ogut G. Conventional enteroclysis with complementary MR enteroclysis: a combination of small bowel imaging. Abdom Imaging 2005;30(5):564-575.

11. Bodily KD, Fletcher JG, Solem CA, Johnson CD, Fidler JL, Barlow JM, et al. Crohn Disease: mural attenuation and thickness at contrastenhanced CT Enterography--correlation with endoscopic and histologic findings of inflammation. Radiology 2006;238(2):505516.

12. Hara AK, Leighton JA, Sharma VK, Heigh RI, Fleischer DE. Imaging of small bowel disease: comparison of capsule endoscopy, standard endoscopy, barium examination, and CT. Radiographics 2005;25(3):697-711; discussion 711-718.

13. Macari M, Megibow AJ, Balthazar EJ. A pattern approach to the abnormal small bowel: observations at MDCT and CT enterography. AJR Am J Roentgenol. 2007;188(5):1344-1355.

14. Maglinte DD, Sandrasegaran K, Tann M. Advances in alimentary tract imaging. World J Gastroenterol 2006;12(20):3139-3145.

15. Fidler J. MR imaging of the small bowel. Radiol Clin North Am 2007;45(2):317-331.

16. Prassopoulos P, Papanikolaou N, Grammatikakis J, Rousomoustakaki M, Maris T, Gourtsoyiannis N. MR enteroclysis imaging of Crohn disease. Radiographics 2001;21 Spec No: S161172. doi: 10.1148/radiographics.21.suppl_1.g01oc02s161.

17. Masselli G, Gualdi G. MR imaging of the small bowel. Radiology 2012;264(2):333-348.

18. Fujii T, Naganuma M, Kitazume Y, Saito E, Nagahori M, Ohtsuka K, et al. Advancing magnetic resonance imaging in Crohn's disease. Digestion 2014;89(1):24-30.

19. Sanli DET, Sanli AN, Kandemirli SG, Esmerer E, Kayadibi Y, Demiryas S, Korman MU. The mutually complementary role of magnetic resonance enterography and conventional enteroclysis in patients with complicated and/or advanced stage of Crohn's disease. Bratisl Lek Listy 2021;122(4):270-276.

20. Solem CA, Loftus EV Jr, Fletcher JG, Baron TH, Gostout CJ, Petersen BT, et al. Small-bowel imaging in Crohn's disease: a prospective, blinded, 4-way comparison trial. Gastrointest Endosc 2008;68(2):255-266.

21. Bruining DH, Siddiki HA, Fletcher JG, Tremaine WJ, Sandborn WJ, Loftus EV Jr. Prevalence of penetrating disease and extraintestinal manifestations of Crohn's disease detected with CT enterography. Inflamm Bowel Dis 2008;14(12):1701-1706.
22. Higgins PD, Caoili E, Zimmermann M, Bhuket TP, Sonda LP, Manoogian B, et al. Computed tomographic enterography adds information to clinical management in small bowel Crohn's disease. Inflamm Bowel Dis 2007;13(3):262-268.

23. Paulsen SR, Huprich JE, Hara AK. CT enterography: noninvasive evaluation of Crohn's disease and obscure gastrointestinal bleed. Radiol Clin North Am 2007;45(2):303-315.

24. Grand DJ, Beland MD, Machan JT, Mayo-Smith WW. Detection of Crohn's disease: Comparison of CT and MR enterography without anti-peristaltic agents performed on the same day. Eur J Radiol 2012;81(8):1735-1741.

25. Grand DJ, Kampalath V, Harris A, Patel A, Resnick MB, Machan J, et al. MR enterography correlates highly with colonoscopy and histology for both distal ileal and colonic Crohn's disease in 310 patients. Eur J Radiol 2012;81(5):e763-769.

26. Ryan ER, Heaslip IS. Magnetic resonance enteroclysis compared with conventional enteroclysis and computed tomography enteroclysis: a critically appraised topic. Abdom Imaging 2008;33(1):34-37.

27. Estay C, Simian D, Lubascher J, Figueroa C, O'Brien A, Quera R. Ionizing radiation exposure in patients with inflammatory bowel disease: are we overexposing our patients? J Dig Dis 2015;16(2):8389.

28. Crellin AJ, Musbahi O, Onwu N, Singh S. Appendiceal Crohn's disease: a rare differential of right iliac fossa pain. BMJ Case Rep 2020;13(2):e232549. doi: 10.1136/bcr-2019-232549.

29. Rábeková Z, Vacková Z, Šerclová Z, Malušková J, Bennett R, Martínek J. Crohns disease of the appendix - a case report. Rozhl Chir 2018;97(12):563-567. (English)

30. Lo Re G, Cappello M, Tudisca C, Galia M, Randazzo C, Craxì A, et al. CT enterography as a powerful tool for the evaluation of inflammatory activity in Crohn's disease: relationship of CT findings with CDAI and acute-phase reactants. Radiol Med 2014;119(9):658-666.

31. Goldberg HI, Gore RM, Margulis AR, Moss AA, Baker EL. Computed tomography in the evaluation of Crohn disease. AJR Am J Roentgenol 1983;140(2):277-282.

32. Yamaguchi A, Matsui T, Sakurai T, Ueki T, Nakabayashi S, Yao T, et al. The clinical characteristics and outcome of intra-abdominal abscess in Crohn's disease. J Gastroenterol 2004;39(5):441-448. 